\title{
THE LATE GOTHIC PORTAL IN TREBIŠOV PAULINE ORDER CHURCH, ARCHITECTURE AND GEOMETRY
}

\author{
Zuzana GRÚŇOVÁ ${ }^{1, *}$, Miloslava BOROŠOVÁ MICHALCOVÁ ${ }^{2}$ Éva VESZTRÓCZY \\ ${ }^{1}$ Department of Building Engineering and Urban Planning, Faculty of Civil Engineering, University of \\ Žilina, Univerzitná 8215/1, 01026 Žilina, Slovakia. \\ 2 Faculty of Education, Matej Bel University in Banská Bystrica, Ružová 13, 97411 Banská Bystrica, \\ Slovakia. \\ ${ }^{3}$ The Slovak Institute in Budapest, Rákóczi út. 15, Budapest, Hungary. \\ corresponding author: zuzana.grunova@fstav.uniza.sk.
}

\begin{abstract}
Gothic architecture is one of the oldest surviving architecture in Slovakia. The Church of Pauline Order in Trebišov has many building phases; its entrance stone portal belongs to the later phase dated about the second half of the 15th century. Paper focuses on an architectural features and geometry of this portal. Portal has clearly a geometrical construction that is compared to another late gothic portal from church in Handlová. Conclusion suggests, that ratio of the entire portal dimensions is close to $4: 3$, proportions of jamb and opening widths are $1: 4: 1$ part of the overall portal width and there highly probably existed some simple method of determining position of pointed arch arches.
\end{abstract}

\section{Introduction}

The Roman Catholic parish church of The Visitation in Trebišov, Slovakia, was declared a national cultural monument on the basis of its heritage values in 1963. The history of the church dates back to the 13th century. Building belongs to the valuable group of the preserved Gothic and Romanesque architecture, one of the oldest surviving architecture in Slovakia along with previous fragments and very rarely whole buildings of the medieval Great Moravian Empire (9th - 10th century). The building development of the church from the beginning to the present reflects religious, artistic and aesthetic demands in connection with political and social events in the region of Eastern Slovakia. Architectural and historical researches in 2010 and 2016 identified the oldest and most valuable architectural elements and medieval murals, some of them are unique in Zemplín region. Those redefined the importance of the parish church not only in the region but in a wider cultural environment.

\section{Trebišov}

Trebišov is a historical town, confirmed as the archaeological site of the Slavonic settlement in the 8th century. [1] The market settlement developed in the 11th century here. The first documented reference to Trebišov in archives comes from the end of the 13th century. The history of Trebišov is associated with many noble families, who played also the important role in developing and preserving the parish church. [2] In 1319 Philip Drugeth became the owner of Trebišov, [3] the Perenyi family owned it in the years 1387 - 1567. Perenyi noble family belonged to the richest and most influential families in Hungary. Drugeth family became owners of the Trebišov again in 1568 until 1684. After several other families, Imrich Csaky acquired Trebišov in 1766 and the last noble house to own and influence Trebišov were Andrassy family in 1834 - 1945. 


\subsection{The Order of Saint Paul the First Hermit in Trebišov}

The arrival of Pauline Fathers, a monastic order of the Roman Catholic Church, was of great importance for the development of the parish church in Trebišov. The male monastic order, devoted to spirituality and pastoral activity, was founded in Hungary during the 13th century. Its way of life - Rule of the Order and its functions in society are relatively well mapped. The first members of the order were mainly from the ranks of noblemen. About 1341 the original brown habit was replaced by white, with a white belt or cincture, and over the white tunic a white scapular with a hood, so they were called "white monks". Up to 19 localities are assumed as the seats of Pauline Fathers on the territory of Slovakia. [4] They arrive in Trebišov at the beginning of the 16th century, when Perényi family owned the town. Political disturbances in Hungary brought the suppression of the most of the Hungarian monasteries after 1783 and Pauline Fathers had to leave Trebišov in 1786. The administration of the parish and the church passed into the hands of the Roman Catholic Church, but the extensive and valuable rococo ceiling paintings inside the church preserve and revive the period when the Pauline Fathers had rendered their incalculable services to religion. [5]

\subsection{The church of the Visitation of Our Lady in Trebišov}

The Roman Catholic Church of the Visitation of Our Lady in Trebišov is situated in the middle of the town, with formerly built up areas of the row building lots, perpendicular to the M. R. Štefánik Street as the central axis of historical urbanism.

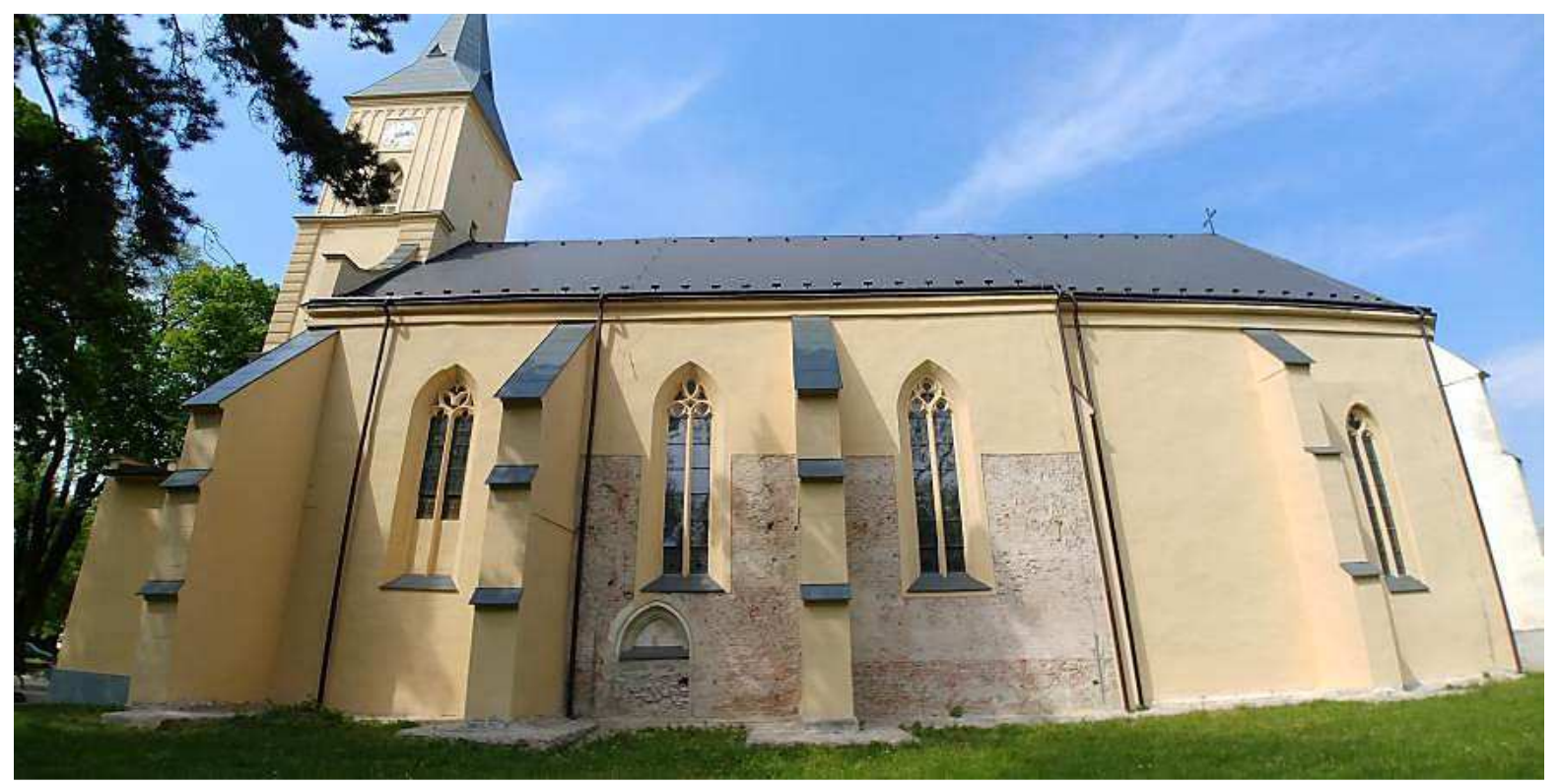

Fig. 1: The Pauline church in Trebišov, south facade with presentation of the Romanesque building phase fragments and Early Gothic phase south stone portal. Photo: Borošová Michalcová, 2018.

Church is the historical and urban dominant. Development and architectural phases from the early Middle Ages, through the late Gothic period, the Baroque period to the present are present and to some extent visible in the architecture of the Pauline Fathers church. All building phases leaved the traces of the architectural and artistic expression, added to the building mass, structures and valuable details. The disposition of the church consists of a one nave and a relatively large presbytery with a polygonal end and a tower on the west side. The U-shaped building of the former Pauline Order monastery was connected to the church's northern side.

The following analysis of the building-historical development of the Pauline Order church in Trebišov is based on the findings of the monumental artistic-historical and restoration research in 2014 as well as the previous knowledge.

\subsubsection{The end of the 13th century}

Small sacral building was built in masonry without plaster - decorative function of the visible masonry was further highlighted by joints with a triangular cross-section. This technique was typical for the late Romanesque and Early Gothic period. [6] In the interior of the church was plastered later and 
decorated with wall paintings. The extent of the original church building could by at least partially identified in the attic space of the church, where are two fragments of the brick wall with the imprint of a high gable roof. It is assumed that the western gable wall of the church was without later high, large gothic point arch window. The shape of the original, later removed presbytery is unknown; it could only be determined by a future archaeological research. Valuable architectural part of the church was the southern stone pointed arch portal. Unfortunately, it has only been partially exposed and cleaned so far, so it is not possible to perform its exact geometric analysis.

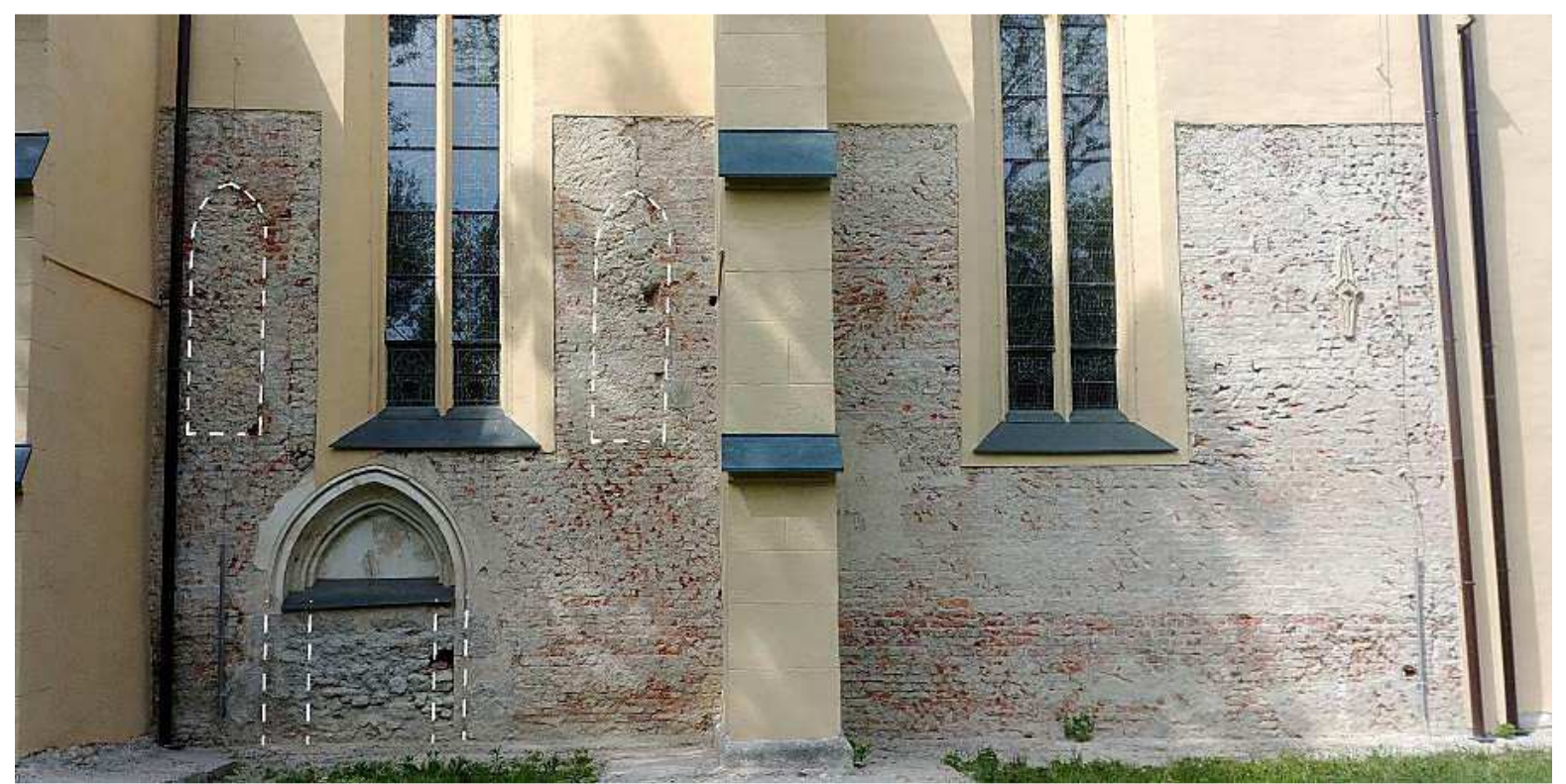

Fig. 2: The Pauline church in Trebišov, south facade with presentation of the Romanesque building phase fragments and Early Gothic phase south stone portal. Photo: Borošová Michalcová, 2018.

\subsubsection{The end of the 15th century}

The first major reconstruction of the church took place in the second half of the 15th century, initiated by Perényi noble family. The new, much bigger sanctuary replaced older one, masonry of the nave was heightened and new windows with gothic stone tracery were located to the south wall of the nave and sanctuary. The interior was crowned with a network of vaults with stone ribs laid upon the pilasters. Corresponding system of supporting pillars with open arcs was provided from the outside of the church. New monastery building was built adjacent to north wall of the church. On the western facade was a profiled stone entrance portal added, which will be analysed in detail (Fig. 3).

\subsubsection{Later building phases}

Western tower was added around 1660 and Pauline Fathers invested into rich rococo painting of the nave and sacristy vaults in 1777 . The church was severely damaged by the earthquake (1834) and the fire (1876) in the 19th century; mainly the roof and wall paintings were damaged. Renovation was sponsored by the Andrassy noble family. Historical wooden roof was replaced in 1892, the wall paintings were restored, and the tower was extended to present height. All facades got the new surface decoration in the historicizing style. Structural problems led to the decision to fill up the openings in the exterior gothic load bearing system. New chapels appeared to south and north of the tower in the 20th century.

\section{The late gothic stone portal}

Portal is located on the western facade of the nave, nowadays in the antechamber under the tower. Rather small pointed arch stone portal was not the main entrance to the church, that function belonged to the southern facade portal (partly uncovered now). Decorative stone struts with drop and pear shaped section of this late gothic portal are typical for the end of the 15th century. Many other examples could be mentioned in Slovakia, Austria, Germany and Czech Republic, e.g. portal of the sacristy, church in Berchtesgaden, Germany (dated circa 1500); Parish church of St. Stephan in 
Weiten, Austria (1473); Basilica of the Assumption in Tismice, Czech Republic (1504); Parish church of St. Bartolomeo, Czech Republic (1507); The Old castle in Banská Štiavnica, Slovakia (circa 1500), Pauline church in Trebišov, Slovakia (circa 1500), sacristy portal of church in Vinné, Slovakia (1484).

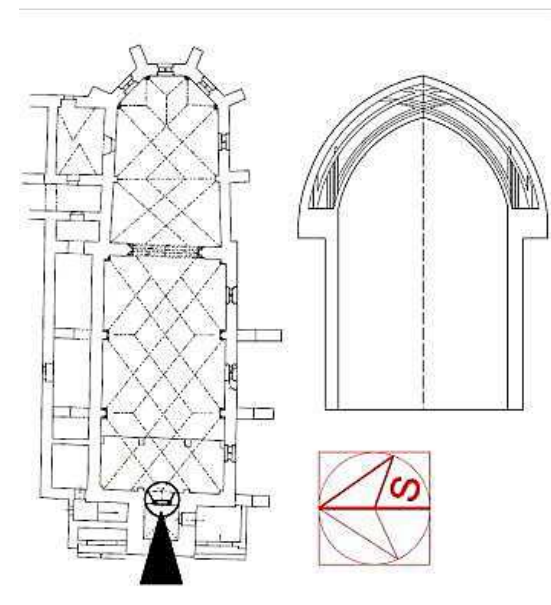

Fig. 3: Pauline church in Trebišov, the late gothic portal of the west facade. Photo: Grúňová, 2014 before renovation 2014 - 2017.

Mass of stone was examined by art-historical research in 2014 by one probe, aimed to uncover relationship of portal and surrounding masonry and plaster layers. Portal was covered by thin lime and paint layer and it is still covered, so exact position of the stone parts was not possible to analyse. Stone portal is about $360 \mathrm{~mm}$ thick, interior side and parts of the opening are damaged, slightly cut, probably to remove degraded worn-down parts. Location and stone parts seem to be complete, no excessive distortions are present, so it is possible to analyse overall geometry and proportions of the portal and its details.

\subsection{Geometrical analysis}

Proportions of the late gothic portal parts clearly bear a witness to the geometry concept. Overall height of portal up to the point of the pointed arch is around $2750 \mathrm{~mm}$, width next to the spring line is $2210 \mathrm{~mm}$. Proportion ratio of the rectangle ABCD (width $\mathrm{x}$ height) is very close to the ratio $4: 3$ or respectively $8: 6$, each unit is $355-360 \mathrm{~mm}$ (see Fig. 4). Jambs (partially covered under the springing line of the portal) are 1 unit wide, opening is 4 units wide. These units ( $8: 6$ or $4: 3)$ do not correspond with other important points of construction, e.g. position of pointed arch centres. The height of springing line is close but it does not lie precisely in the $8 \times 6$ or $4 \times 3$ mesh. Position of the stone bars could indicate composition positioned to thirds of the jamb's width. Jambs are covered by modern painting in the bottom part of the portal and this coverage about $2 / 3$ of the jamb is purely coincidental and probably in relation to the new historicizing doors.

Height of the springing line of the portal KL is about $1770 \mathrm{~mm}$ from the doorstep line $\mathrm{AB}$. The whole rectangle ABLK proportions are close to $5: 4$ ratio, spring line KL divides the whole height of the portal $3: 2$ parts (see Fig. 5). Clear opening of the portal, rectangle EFGH has a ratio, which is closest to the $6: 5$. However, any of the meshes intersections (ABLK $5: 4$ parts or EFGH $6: 5$ parts) do not indicate localization of any important points or lines, so this ratios were not probably taken into consideration when constructing portal geometry. 


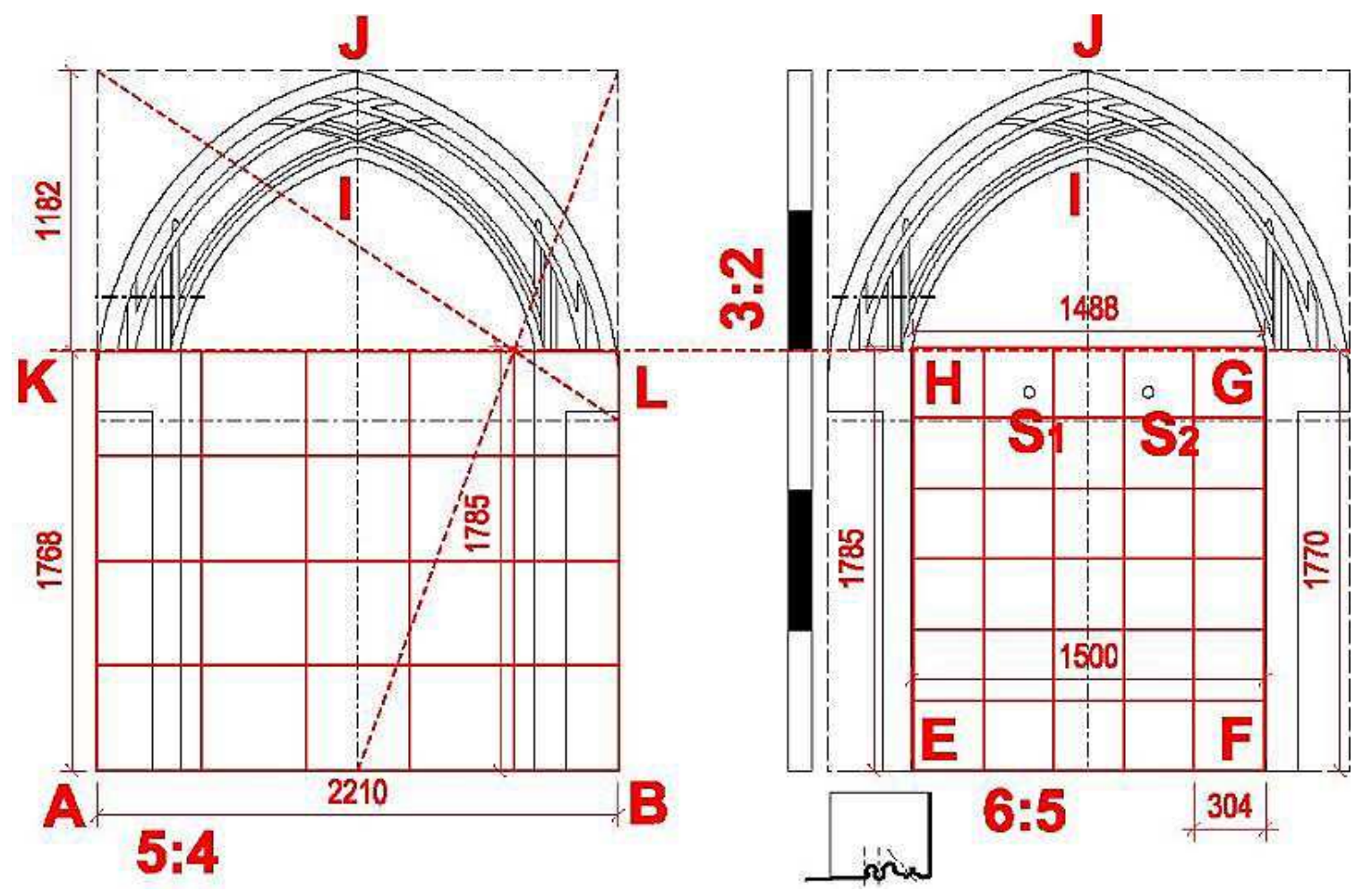

Fig. 5: Pauline church in Trebišov, the late gothic portal. Proportions of the rectangle ABLK up to springing line left and proportions of the opening to the right.

Only one hypothesis seem to emerge - springing line KL could be very simply constructed as horizontal line through intersection of diagonal lines, connecting points of outline rectangle ABCD and centres of the opposite lines. Line from $\mathrm{C}$ to centre of $\mathrm{AB}$ and line from $\mathrm{D}$ to the $\mathrm{L}$ (centre of $\mathrm{BC}$ ) are drawn in the Fig. 5, resulting horizontal line is a few mm away from the springing line KL.

\section{Comparison and conclusions}

Some of other geometrical features will be discussed and illustrated in comparison to another late gothic portal.
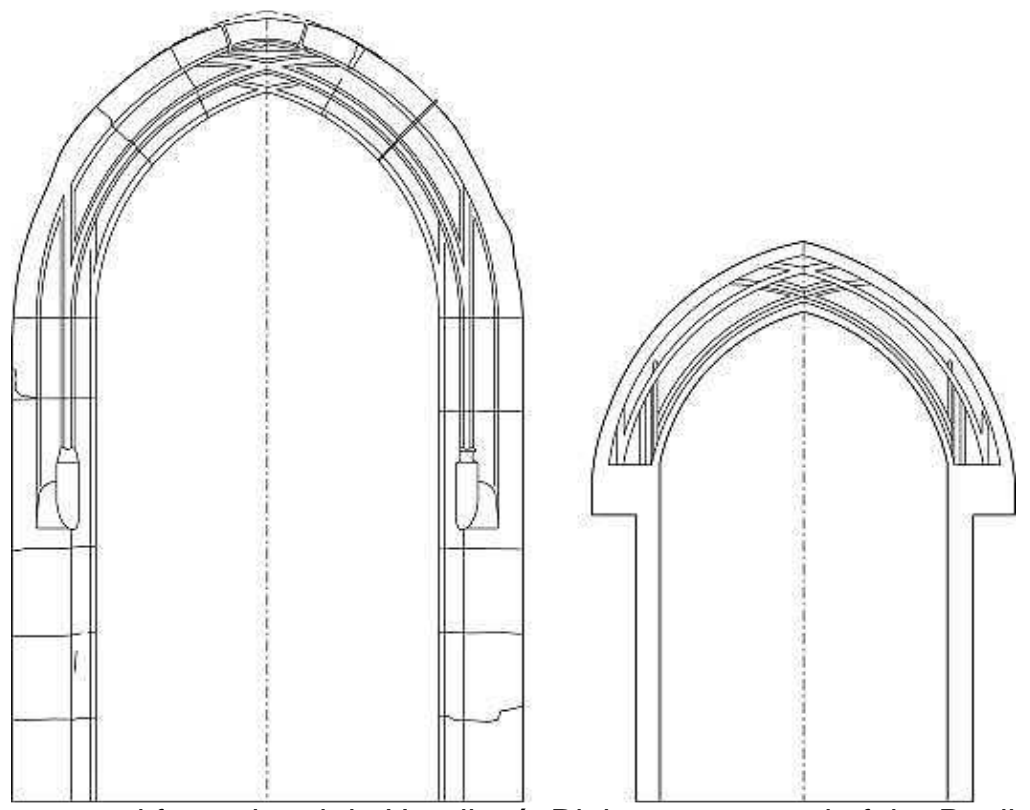

Fig..6: Left: Stone portal from church in Handlová; Right: stone portal of the Pauline church in Trebišov. Drawing by Grúňová, 2018. The same scale is used for both portals. 
The church of St. Catherine of Alexandria in Handlová (Slovakia) has in a shape, features etc. similar stone portal, dated to the phase of renovation in 1502. It is also an entrance portal, but a bit larger and more representative, because The St. Catherine's church was the church of the rich town with long mining tradition and it was the main church entrance portal. Its history and geometry of the portal see in detail in [7].
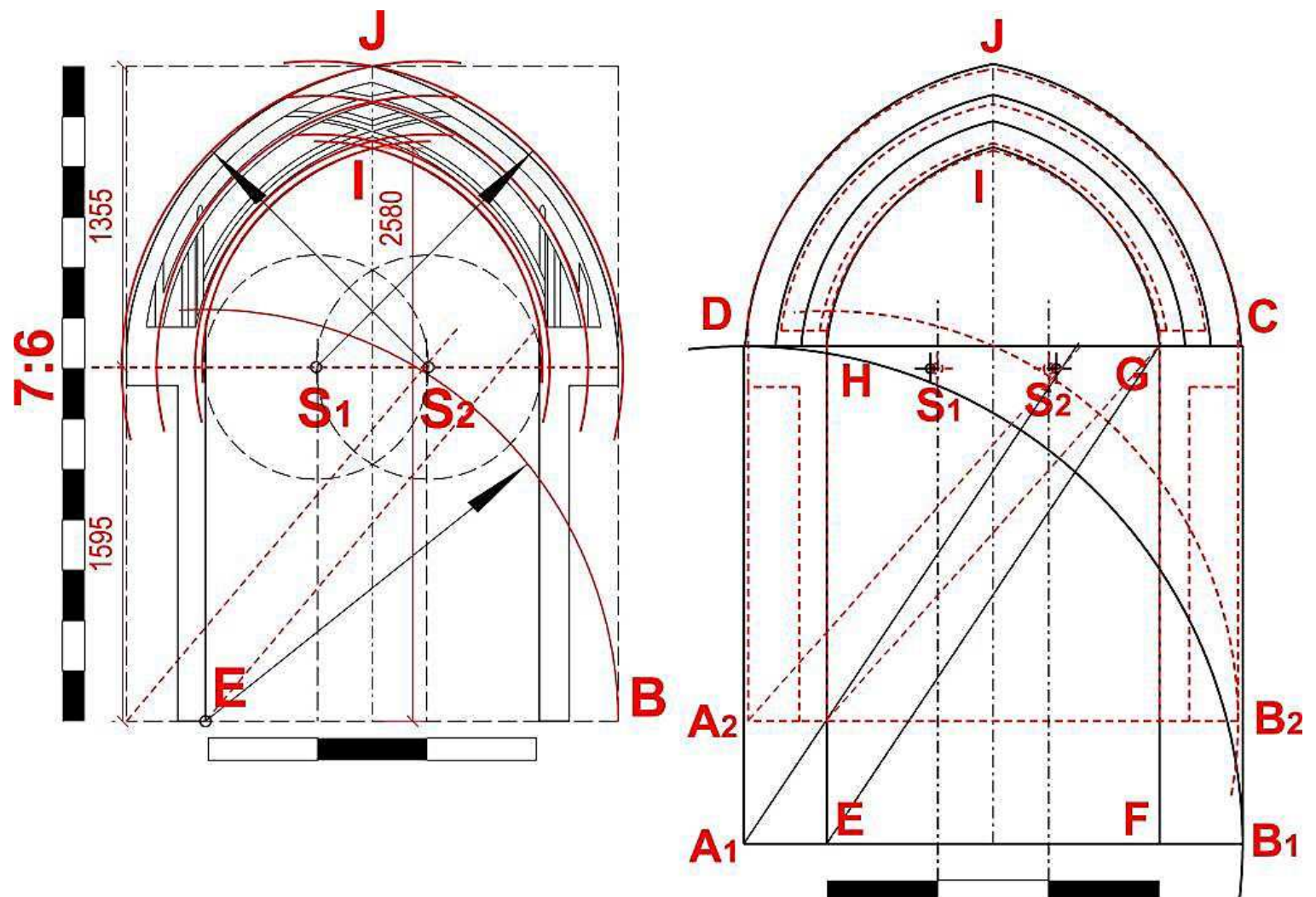

Fig. 7: Left: a) Portal of Pauline church in Trebišov; Right: b) comparison of portal from Trebišov in red dashed lines superimposed on the Handlová portal (dated 1502) in continual black lines. Both portals outlines are correlated in width of the opening, because authors supposed, that dimensions (ratios) of the opening could be an important determining factor in door - portal design.

Both portals main geometry outlines are superimposed in Fig. 7. This way it is possible to compare proportions and ratios regardless of differences in real dimensions.

Portal from Handlová church is based on the square. Horizontal coordinates of the centres S1 and S2 lie close to the thirds of the opening width. Portal from Trebišov is based on rectangle with $5: 4$ ratio. Horizontal coordinates of the centres S1 and S2 lie also close to the thirds of the clear opening width. Vertical coordinates of the centres S1 and S2 positions are not so easily explained. They lie definitely below the springing line of either portal. In the case of Trebišov portal, their position could be explained as an intersection of vertical line (1/3 and $2 / 3$ of the opening width) and arch with centre in $E$ with radius of EB (see Fig. 7a). But that is not the case for Handlová portal.

Hypothesis about geometrical construction of pointed arch centres that emerged in [7] is applicable also in Trebišov case. Diagonal line EG (see Fig. 7b) is constructed as a diagonal the portal opening. Line parallel to EG is then constructed through point A1 (or A2). This parallel line intersects vertical line in the third of the opening width (dash-dot black line in Fig. 7.). Intersection lies in the both cases - Trebišov and Handlová - very close to pointed arch centre S2 (and symmetrically it is possible to construct centre S1). Authors plan to analyse more of the late gothic portals to further discuss this suggested procedure of construction.

Portal jambs are in the both cases proportionate to the overall dimension of the portal, but superimposed comparison show that this proportion seems to be based on the same procedure or design. If overall portal width is divided into 6 parts, then opening width is 4 parts and jambs are wide 1 part each (see Fig. 4).

Conclusions of the geometrical analysis of portal in Handlová suggest that ratio of width to height of the entire portal could be close to $2: 3$ or $5: 8$ to suggest some consideration, but it was not 
a primary goal to attain precise ratios. The stone cutter just followed many times repeated geometrical procedure - square and the pointed arch, based on it [7]. Portal from Trebišov church has a reasonable looking overall ratio of $4: 3$. But the possibility of such a predetermined overall ratio would imply existence of some procedure (probably purely geometric) to reverse engineer shape and centre of the pointed arches and at the same time maintain some desired ratio of the rectangle (even square) with overall portal width by height up to the springing line from the overall dimensions. Bottom up procedure would be much simpler - determine desired width of portal and opening, then construct desired rectangle (square) up to the springing line and then construct centres of pointed arch arches. Overall ratio close to $4: 3$ would be in the case of Trebišov church's portal just coincidental result.

\section{References}

[1] ULIČNÝ, F.: The beginnings and development of Trebišov up to the end of the 16th century. Východoslovenské vydavatel'stvo Košice, 1982 (in Slovak).

[2] PELLOVÁ, D.: Archive research of the Trebišov church. Art-historical research of national monument, The Church of the Visitation of Our Lady in Trebišov. 2014, manuscript archived in Office for monument preservation, Košice (in Slovak).

[3] KOHÚTOVÁ, M.: Noble family of Drugeth. Historická revue 10, Vol. VII, p. 8 (in Slovak).

[4] ZEMENE, M.: About monastic orders in Slovakia. Conference proceedings. University of Trnava, Trnava, 1994, p. 44 (in Slovak).

[5] JÁVOR, A.: Secular wall paintings in the Northeastern Hungary. Art education and artistic studies. Müvészettörténeti tanulmányok, Budapest, 1978 (in Hungarian).

[6] HABOVŠTIAK, A.: Contribution of medieval archeology to the study of Romanesque brick churches in Slovakia. Sborník Československé Společnosti Archeologické, 1961 (in Slovak).

[7] GRÚŇOVÁ, Z.: Geometry of the Late Gothic portal in Handlová church. Civil and Environmental Engineering, Vol. 14, Iss. 1, 2018, pp. 69 - 75. 